In order to complete the first volume of the österreichische Städtebuch as soon as possible, attention will especially be concentrated on the Provinces of Upper and Lower Austria, where, on account of the preliminary work that has already been done, the most and the best work has been accomplished. Furthermore, over half of the cities of Austria are in these two provinces.

In an effort to arouse interest in the program, Prof. Alfred Hoffmann, the director of the Institute for Economic and Social History at the University of Vienna, discussed the general problem of urban history research, and particularly the work being done on the österreichische Städtebuch, in a private lecture to eighteen people. Several competent people were recruited from this group to help with the project.

A central office is to be established within the framework of the Commission for Urban History Research of the Austrian Academy of Sciences to carry out the editorial work in cooperation with the Institute for Economic and Social History at the University of Vienna.

In addition to the work that is being done on the österreichische Städtebuch, preliminary preparations are now being made for a similar investigation of Austrian market places and for the publication of a Bibliographie zur österreichischen Stadtgeschichte.

Institute for Economic and Social History,

ALOIS MOSSER University of Vienna

\title{
NEWS FROM HUNGARY
}

A committee which was appointed to study the history of the Austro-Hungarian monarchy decided at its yearly meeting in Prague in 1962 to prepare an international bibliography of work dealing with this subject. The Rumanian Academy of Sciences assumed the editorial and publishing responsibilities for the project. At a conference held in Budapest in May, 1964, the principles and methods for collecting and editing the materials were agreed upon. It was decided that the whole period from 1789-1918 was to be covered. All books, articles, and review essays published in the German Democratic Republic, Bulgaria, Czechoslovakia, Hungary, Poland, Rumania, Yugo- 
slavia, and the Soviet Union between 1945 and 1964 were to be included. The bibliography was not to be arranged by countries, but by periods (1789-1815, 1816-47, 1848-49, 1849$66,1867-1914$, and 1914-1918) and by subject matter: (1) sources and bibliographies; (2) economic history; (3) social and political history and the history of institutions; and (4) the history of arts, sciences, etc.

The work of collecting and arranging the entries was finished during the summer of 1965. The manuscript now contains more than 6,000 titles, giving the bibliographical details about the book, article, or review essay in the original language and in German translation. Where the title gives no clear indication of the content of the work, the editors have added a short annotation. At the end of the entire work there is to be an index to help the reader in using the bibliography. The editorial board, which is composed of experts from all participating countries, dealt with the final problems involved in editing the work when it met in Bucharest in the fall of 1963. Plans are being made to have the bibliography published towards the end of 1966.

Historical Institute PÉTER HANÁK

of the Hungarian Academy of Sciences

Professor Gy. Ránki, assistant director of the Institute for Historical Research of the Hungarian Academy of Sciences, will be in the United States on a Ford Foundation grant from February to July, 1966. Professor Ránki is doing research on nineteenth century economic history.

\section{NEWS FROM GREAT BRITAIN}

Carlile A. Macartney, of Oxford University, the well known historian of the Danubian area and particularly of Hungary, celebrated his seventieth birthday on January 24, 1965.

\section{NEWS FROM THE UNITED STATES}

\section{THE AUSTRIAN INSTITUTE}

During the past year and a half most of the activities of the Austrian Institute have been concentrated on fine arts 